\title{
Finding the Exit: Ideology and Aperture in Graciliano Ramos
}

\section{Holly Jackson}

University of California at Berkeley

\begin{abstract}
What ideological structures produce the linguistically austere worlds of Graciliano Ramos's novels? What are the effects of reading outside of these seemingly all-consuming structures? These questions motivate this article's discussion of two novels: São Bernardo and Vidas secas. In recuperating the complexity of expression in Graciliano's writing, the article explores distinct modes of language as resistance to stereotypes about Brazilian Northeasterners-stereotypes that are often reproduced in literary criticism. The article considers this resistance both within language, in misuse (circularity, lying, [mis]appropriation, the breakdown of narrative time), and to language, in the textual presence of silence.
\end{abstract}

Keywords: São Bernardo, Vidas secas, Brazilian Regionalism, silence, narrative time

The theme of futility is a current in much of the critical work on Graciliano Ramos's writing. Graciliano’s works are "uma sátira violenta e um panfleto furioso contra a humanidade" (Lins 132); "uma série de experiências de humilhação, de degradação, físicas, morais ou psicológicas" (Casais Monteiro 166); "[um] sistema literário pessimista" where all humans "obedecem a uma fatalidade cega e má ... que os leva a caminhos pré-traçados" (Candido, "Ficção" 53). Although characters may attempt to transform their surroundings, "sabem que todo é inútil" (Sarmento Lima 15). Obedience to broad power structures that predetermine subjectivities subsumes individual realities: the inhabitants of these worlds "rodam num âmbito exíguo, sem saída nem variedade" (Candido, "Os bichos" 87). 
What ideological structures create these worlds? Is it possible to identify an "outside" to these worlds within the text? If so, what are the effects of performing such a reading? These questions motivate this article, in which I examine how Graciliano represents ideology and its outside in two of his novels: São Bernardo (1934) and Vidas secas (1938).

Graciliano himself poses the question of ideology and freedom in terms of the problematics of language in his autobiographical Memórias do cárcere: "Liberdade completa ninguém desfruta: começamos oprimidos pela sintaxe e acabamos às voltas com a Delegacia de Ordem Política e Social, mas, nos estreitos limites a que nos coagem a gramática e a lei, ainda nos podemos mexer" (34, italics mine). What emerges from this quote is that for Graciliano, language is at once the instrument of and the means of resistance to ideology.

In this article, I argue that both São Bernardo and Vidas secas channel discourses that are alternative to that of hegemonic language and consequently resistant to the imposition of ideology. One of these discourses is silence-a presence, rather than an absence, in the text. These novels represent worlds in which ideological apparatuses seem inevitable; however, the novels disprove the inexorability of ideologically determined existence. Through close readings of the texts, I first identify the ideological apparatuses at work in each novel, calling attention to the conflation and equation of ideology, language and time. In the next section of the paper, I identify possible apertures in these apparatuses, including parallel scenes of existential crisis. I conclude that in their resistance to language and in their openness to alternative discourses, these novels belie the notion of ideologically closed-futile-worlds; further, this internal resistance with regard to language calls into question the critical tradition that exists around the so-called Regionalist literature of Brazil's Northeast. Graciliano's novels, traditionally held to be part of the Regionalist canon, refuse to impose or perpetuate certain identities and languages-that is, certain ideologies-on the region and its inhabitants, and therein call for a critical approach to Northeastern Regionalism that acknowledges the complexity of its expressive modes. 


\section{Closed Worlds}

In São Bernardo, a suffocating economic system permits no outside: "Dinheiro é dinheiro," Paulo Honório advises (19). From this tautology unfold many of the novel's implications, first among them the single-mindedness of Paulo Honório's motivations with regard to acquisition. Material possession is Paulo Honório's paradigm and his language. To this effect, his monetary axiom also suggests that money is the only thing that is truly itself; everything else undergoes a translation into an economic language.

Economic power constitutes a relentless narrative lens focalized through the voice of Paulo Honório. His language constantly sublimates the social to the economic. Thus, the idea of Paulo Honório's memoir is simultaneous with the idea of its selling potential: "já via os volumes expostos, um milheiro vendido" (7); fame is a commodity he purchases: "Costa Brito também publicou uma nota na Gazeta, elogiando-me.... Em conseqüencia mordeu-me, cem mil-réis" (42-43); justice is an economic luxury: "Como a justiça era cara, não foram à justiça" (40); religion is an economic reckoning: "Admito Deus, pagador celeste dos meus trabalhadores, mal remunerados cá na terra, e admito o diabo, futuro carrasco do ladrão que me furtou uma vaca de raça" (131); holidays hinder economic gain: "Aqui nos dias santos surgem viagens, doenças e outros pretextos para o trabalhador ganzear. O domingo é perdido, o sábado também se perde, por causa da feira, a semana tem apenas cinco dias, que a Igreja ainda reduz. O resultado é a paga encolher" (56); birth is a compensation: "Madalena estava prenhe.... Uma compensação" (113); and death is an affront to productivity: "Para diminuir a mortalidade e aumentar a produção, proibi a aguardente" (38-39); “[n]ão obstante ele ter morrido, acho bom que vá trabalhar” (102-03).

Paulo Honório writes himself into this discourse of economic potentiality, condensing his present and past into a trajectory of acquisition, understanding marriage and children as the procurement of an heir, and couching his marriage proposal and reconciliation in terms of job offers $(15 ; 59 ; 88-89$, 106). Paulo Honório both subordinates others to and is himself an interpellated subject of this ideology. While other characters in the novel may be "meras modalidades do narrador," as Antonio Candido has put it, "Paulo Honório, por sua vez, é modalidade duma força que o transcende e em função da qual 
vive: o sentimento de propriedade" ("Ficção" 24). According to João Pereira Pinto, Paulo Honório "não é livre.... Comporta-se dentro da ideologia dominante, sem ter consciência desse fato" (133). This drive for property consumes Paulo Honório as he consumes others. After his wife commits suicide and the property declines, he reflects: "nem sequer me resta a ilusão de ter realizado obra proveitosa. O jardim, a horta, o pomar-abandonados; os marrecos de Pequim-mortos; o algodão, a mamona-secando. E as cercas dos vizinhos, inimigos ferozes, avançam" (181).

In the same way that Paulo Honório’s power dissolves back into the ideological apparatus of possession, one imagines a bastardization of his name, yet another sublimation to the economic-from the strongman implications of "Honório," a slippage to honorários, legal fees. Possession is not a permanent condition that endows the "personalidade forte" of Paulo Honório with individuality (Candido, "Ficção" 28); rather, it is an ideological drive to which he is subjected and of which his downfall is merely a reaffirmation. If in São Bernardo the drive for possession is all-consuming, in Vidas secas it is deprivation that is inescapable. As in São Bernardo, this reality exists in language.

In Vidas secas, Fabiano and his family are retirantes, subjects of the drought cycle. As a character, Fabiano evokes Os Sertões, "onde Euclides da Cunha descreve a retidão impensada e singela do campeiro nordestino" (Candido "Ficção" 45). Similar to Euclides' study of sertanejos, whose physicality conjures an image of "Hércules-Quasímodo" (Cunha 48), Graciliano’s descriptions of Fabiano suggest a predetermined identity: "Êsses movimentos eram inúteis, mas o vaqueiro, o pai do vaqueiro, o avô e outros antepassados mais antigos haviam-se acostumado a percorrer veredas, afastando o mato com as mãos" (21-22).

The majority of the novel is told in the free indirect discourse of Fabiano; within this interiority is revealed the inculcating effect of the social order. Fabiano's internalization of the status quo results in him repressing any ideation of his own agency. Despite his development of a theory of the injustice of the social order over the course of the novel, Fabiano never utters this aloud and instead accepts his situation as fate: "Tinha obrigação de trabalhar para os outros, naturalmente, conhecia o seu lugar.... Era sina. O pai vivera assim, o avô também.... Comformava-se, não pretendia mais nada" (143). 
The invocation of his bloodline here echoes his previous mention of his ancestors with regard to posture; these passages establish a rhetoric of social determinism that would naturalize the social hierarchy to which Fabiano is subject. Fabiano's laconism illustrates not the biological limits that this deterministic rhetoric would ascribe to him, but the process by which this ideological apparatus reproduces itself: "Se Fabiano silencia, é porque alguém manda que ele o faça. Desde pequeno, ele foi 'educado' para agir assim. A censura começa na infância" (Santos 50-51).

Throughout Vidas secas, the sertanejo's function in society is submission to authority. This dynamic manifests itself, within Fabiano's perspective, in the problem of language. Fabiano's lack of vocabulary results not only in his inability to assert himself but also in his alienation from society. When he does try to communicate with the townspeople, they ignore him. In fact, despite Fabiano's hypersensitivity to the other bodies around him during a feast day celebration, the townspeople fail to perceive his existence: "Evidentemente as criaturas que se juntavam ali não o viam" (110-11). Drunk, Fabiano attempts to engage the townspeople in a fight, but his speech goes into a void. He calls out incitements to the crowd, but no one hears: "ninguém notou a provocação" (114-15); "[1] ançava o desafio numa fala atrapalhada, com o vago receio de ser ouvido. Ninguém apareceu" (115). It is not just his drunken belligerence that renders his language unhearable. A similar problem of mute speech arises when he tries to stand up to his boss in the chapter "Contas." Unheard indictments against the boss and the social order in general run through the chapter, even as Fabiano repeatedly denies his own right to expression: "Não podia dizer em voz alta que aquilo era um furto, mas era” (140); “[n]em lhe permitiam queixas” (140); “[n] em lhe restava o direito de protestar" (142). The narrative ties social injustice, then, to an inability to enunciate.

Desirous of social access through language, Fabiano channels the spectral figure of Tomás, a literate sertanejo defeated by the drought. Tomás's ability with language is at once an inspiration and a cautionary tale to Fabiano. On the one hand, Tomás's knowledge inspired respect: "Quando seu Tomás da bolandeira passava.... Fabiano e outros semelhantes descobriam-se" (28). On the other hand, "[d]os homens do sertão o mais arrasado era seu Tomás da 
bolandeira. Porquê? Só se era porque lia demais" (28). To Fabiano, the mastery of language is ultimately incongruous with the reality of a sertanejo subjectivity: "Para que lhe servira tanto livro, tanto jornal? Morrera por causa do estômago doente e das pernas fracas" (32). Fabiano’s imaginings of Tomás are an internal conflict between a desire for language and a sense of a predetermined subjectivity that would preclude his use of language.

When a soldier finally engages Fabiano in conversation, the latter cannot find the language to decline the invitation to gamble: “-Isto é. Vamos e não vamos. Quer dizer. Enfim, contanto, etc. É conforme. Levantou-se e caminhou atrás do amarelo, que era autoridade e mandava. Fabiano sempre havia obedecido" (36-37). Fabiano's obedience is a reflex that supersedes his attempt to assert himself verbally. The soldier later starts a fight with and incarcerates Fabiano. In jail, Fabiano conflates his subjectivity with animality, death and the lack of language: "Na beira do rio haviam comido o papagaio, que não sabia falar. Necessidade. Fabiano também não sabia falar" (47).

Even though the interior language of Fabiano and his family comprises the narrative, the last lines of the novel generalize and naturalize what has been up until now a representation of individuals with complex interiorities: "Chegariam a uma terra desconhecida e civilizada, ficariam presos nela. E o sertão continuaria a mandar gente para lá. O sertão mandaria para a cidade homens fortes, brutos, como Fabiano, sinha Vitória e os dois meninos" (193). Abandoning the free indirect discourse of Fabiano and Vitória, the narration affirms that they are not individuals but rather subjects of an inexorable cycle of oppression.

\section{Ideological Crises and Apertures}

Possession, dispossession, and the oppression of social hierarchy compose the ideological worlds of São Bernardo and Vidas secas. The questions of analysis remain: where do these worlds experience fissure? And what consequences are entailed in the existence of a (literary) outside to ideological apparatuses?

In São Bernardo, Madalena’s association with the workers undermines Paulo Honório's ideological production of the space of São Bernardo; her stubborn disavowal of Paulo Honório's paradigm constitutes the latter's obsession and ultimate self-destruction in the second half of the novel (Lafetá 204). Paulo 
Honório's inability to affect (both in the sense of influencing and in the sense of assuming the voice of) Madalena through language is the central conflict from the beginning of their relationship: "Tive, durante uma semana, o cuidado de procurar afinar a minha sintaxe pela dela, mas não consegui evitar numerosos solecismos. Mudei de rumo. Tolice" (95). The profound disconnect between their languages is evident through their last interaction, where Paulo Honório intercepts Madalena with language that still seeks to impose a discourse of economic strategy on the relationship: "Temos negócio" (157). To this and to the vitriol that follows, Madalena responds anaphorically: "Ainda? ... Ainda?" (158). Her refusal to engage flusters Paulos Honório's: “-Fale, exclamei com voz mal segura” (159).

The inaccessibility of Madalena’s language for Paulo Honório affords her a discursive space apart. Even the interpolation of her suicide note in Paulo Honório's own written document does not effect an ideological interpellation. Paulo Honório fails to understand Madalena's language when he finds a page of her suicide note; even when he has the complete letter, contextualized in the act of Madalena's suicide, she remains unknowable to him: "topava a cada passo aqueles palavrões que a minha ingnorância evita” (165-66). If Madalena’s language is impenetrable for Paulo Honório, neither can he write her in his own language: "E, falando assim, compreendo que perco o tempo. Com efeito, se me escapa o retrato moral de minha mulher, para que serve esta narrativa? Para nada" (101). The tenuous connection between Madalena and Paulo Honório's language results in the failure of his ideology to comprehend her.

In her compassion for others, Madalena asserts an alternative to Paulo Honório's acquisitiveness. After her suicide, Paulo Honório comes to perceive his own "brutalidade," "egoísmo," and "deformidades monstruosas" (187): "Se Madalena me via assim, com certeza me achava extraordinariamente feio" (187). Here, Paulo Honório locates Madalena outside his own ideology, and she is therefore in a position to judge it. In fact, Madalena's compassion effects not just a new self-consciousness but also an epistemological crisis in Paulo Honório. This happens in chapter nineteen, in which Paulo Honório narrates a sudden tailspin of time, space and his own identity. The passage comes after his first clash with Madalena over the conditions of the workers and his uneasy recognition that Madalena "era boa em demasia" (101). 
Before parsing the kaleidoscopic temporalities of this passage, the relationship of time to ideology in the novel must be established. The destabilization of time in chapter nineteen is important because of the absolute control Paulo Honório exerts over time in the rest of the novel. His narration is a chronometer, explicitly marking time. Such signposting is present from the first few paragraphs of the novel: "Estive uma semana" (7); "pedalando meia hora" (8); "[q]uinze dias depois" (8). João Luiz Lafetá points to two purposes that this serves, the first being an affirmation of the narrative's objectivity and the second being the fulfillment of Paulo Honório's acquistive designs: "o jogo ... depende, para seu êxito, do enredamento de Padilha em um tipo especial de tempo" (194). In both senses, which can be characterized respectively as a rhetorical and a material use of time, the significance of time is ideological; through his use of time, Paulo Honório stakes a claim on historiographical truth in his narrative and deploys possessive strategies. To the extent that the chronometrically-obsessed narration of São Bernardo corresponds to the ideological forces that drive its action and the space of the fazenda, the novel assumes a particular chronotope, in the Bakhtinian sense of a literary representation of time and space where time "thickens, takes on flesh, becomes artistically visible" and space "becomes charged and responsive to the movements of time, plot, and history" (Bakhtin 15). In Paulo Honório's language, time (authoritarian in its orderliness) and space (understood through its conquest) derive from the ideology of material acquisition; this ideology is in turn made real through the control of time. In other words, time is ideology; and if time is ideology, then the rupture of time signals a rupture in ideology.

Throughout São Bernardo, there are two principal temporalities, corresponding to two distinct narrative strands-the homodiegetic narrative, which consists of Paulo Honório's life and downfall; and the extradiegetic narrative, which consists of Paulo Honório's writing of his life. It is evident that the homodiegetic Paulo Honório is different from the extradiegetic one: where the former is an embodiment of the ideology of material acquisition, the latter is tormented by regret and self-doubt.

Although the extradiegetic temporality is almost exclusive to the first and last chapters of São Bernardo, in chapter nineteen it invades the homodiegetic 
narrative, destabilizing space and time. It is Paulo Honório's sense of the futility of his language to capture Madalena that invokes extradiegetic time, which devolves into the time of memory:

Emoções indefiníveis me agitam-inquietação terrível, desejo doido de voltar, tagarelar novamente com Madalena, como fazíamos todos os dias, a esta hora... Procuro recordar o que dizíamos. Impossível. As minhas palavras eram apenas palavras, reprodução imperfeita de fatos exteriores, e as dela tinham alguma coisa que não consigo exprimir. Para senti-las melhor, eu apagava as luzes, deixava que a sombra nos envolvesse até ficarmos dois vultos indistintos na escuridão. (101-02)

Here, Paulo Honório's memory of listening to Madalena avers a tenderness absent from the homodiegetic narrative of their life together. Similarly, the erasure of boundaries between their two bodies in the darkness mitigates the disconnection between their languages, effecting a disembodiment of language.

The instability of this passage comes to bear on Paulo Honório's proprioception: "A voz dela [Madalena] me chega aos ouvidos. Não, não é aos ouvidos. Também já não a vejo com os olhos. Estou encostado à mesa, as mãos cruzadas. Os objetos fundiram-se, e não enxergo sequer a toalha branca” (102); "[a] toalha reaparece, mas não sei se é esta toalha sobre que tenho as mãos cruzadas ou a que estava aqui há cinco anos" (103); "estou sossegado: as mãos continuam cruzadas sobre a toalha e os dedos parecem de pedra. Entretanto ameaço Madalena com o punho" (103). In this series of indeterminate self-perceptions, Paulo Honório fails to locate his own existence in time and space, as he fails to articulate his agency within the world. At the end of the chapter, there is a symbolic failure of the clock: "O que não percebo é o tique-taque do relógio. Que horas são? Não posso ver o mostrador assim às escuras. Quando me sentei aqui, ouviam-se as pancadas do pêndulo, ouviam-se muito bem. Seria conveniente dar corda ao relógio, mas não consigo mexer-me" (104). The opening of a consciousness apart from Paulo Honório's own ideological drive disarms his chronometry.

This experience of temporal and ideological rupture necessarily extends to language. Throughout the chapter, language eludes Paulo Honório: “A voz 
de Madalena continua a acariciar-me. Que diz ela?" (102); "seu Ribeiro está conversando com d. Glória...Esqueço que eles me deixaram e que esta casa está quase deserta" (103); "a palestra de seu Ribeiro e d. Glória é bastante clara. A dificultade seria reproduzir o que eles dizem. É preciso admitir que estão conversando sem palavras" (104). The loss of a denotative language, elsewhere the principal mechanism in the ideological apparatus of materialism, is a torturous experience for Paulo Honório: "Repito que tudo isso continua a azucrinar-me" (104). In fact, the very process of writing-his attempt to repair the past (Madalena's suicide) through language-parallels the frustration of time and space. The right words escape him: "Releio algumas linhas, que me desagradam. Não vale a pena tentar corrigi-las. Afasto o papel” (101).

If chapter nineteen of São Bernardo reveals an outside to time and language, the narrative promptly resolves back into the ideological order to which Paulo Honório and the others are subjects. Paulo Honório dismisses the experience: "Mas isto passa" (104). However, there are two characters, peripheral to both Paulo Honório's narrative and society, whose embodiment of the quality of being outside language and time calls for analysis: Margarida and Casimiro Lopes.

The first of these is a black candy seller who is a stand-in for Paulo Honório's ancestors. Margarida is dying, as Paulo Honório comments: “Tem um século, e qualquer dia destes compro-lhe mortalha e mando enterrá-la” (13). Michel de Certeau's notion of the dying as the ultimate social deviants is an apt lens through which to understand Margarida's position outside of ideology in the narrative. In particular, the notion that the dying person's "absence of work is non-sense" would seem to be true within the ideology and language of possession (Certeau 191). To have no use value is to lack meaning within the discourse of material possession. If her proximity to death frees her from ideological subjectivity, so does her material simplicity. She rejects Paulo Honório's attempt to furnish her house: "Para que tanto luxo? Guarde os seus troços, que podem servir.... É o que eu preciso, o fogo. O fogo e um pote" (58). What Paulo Honório perceives as Margarida's dispossession is in fact her foreignness to the ideology of material possession; Paulo Honório cannot inscribe Margarida in this discourse.

As with Margarida, the near-silent Casimiro Lopes occupies an existence apart from the rise and fall of São Bernardo. Despite his role as São Bernardo's 
sentinel and the hit man in Paulo Honório's schemes, there is no indication of his existential attachment to the property or Paulo Honório's ambitions. He is a-moral, in the sense that he operates outside of the framework of morality and "não guarda a lembrança do mal que pratica.... Não compreende nada, exprime-se mal e é crédulo como um selvagem" (136). Although in this figuration Paulo Honório oversimplifies Casimiro to the point of depriving him of thought, the very fact that any interiority evades Paulo Honório's discourse signals Casimiro's otherness. If the recurrent association between Casimiro and the dog underscores Casimiro's "fidelidade de cão" to Paulo Honório (15), it also suggests his removal from the sphere of human ambition to possess. In the same way, Casimiro's communication happens outside language. $\mathrm{He}$ speaks only twice: the first time, his language fails to connect with the language of the city-wise Padilha (56); the second time, he recuses himself from the political ambit of the other workers with the hermetic and seemingly anachronistic comment that "as coisas desde o começo do mundo tinham dono" (60). To a greater degree than the other characters of the novel, Casimiro is subject to Paulo Honório's narrative self-centrism, at times appearing to be a mere alter-ego of the narrator himself. Thus, Casimiro comes into existence in the narrative in relation to Paulo Honório's needs: "Casimiro Lopes pergunta se me falta alguma coisa" (10); and then crouches down, awaiting orders. Paulo Honório conflates their identities: "E não me espantaria se me afirmassem que eu e Casimiro Lopes éramos uma pessoa só” (143). However, the divergence of the two identities at the end of the novel establishes Casimiro's freedom from the ideological apparatus that torments Paulo Honório. The revelation is reminiscent of the Hegelian master-slave dialectic: Casimiro, having never ventured his individuality, retains an existential freedom, even as Paulo Honório's all-consuming individuality ends up distorting his world. While Paulo Honório finds himself condemned to a futile project of language, Casimiro sleeps: "Que miséria! Casimiro Lopes está dormindo...E eu vou ficar aquí, às escuras, até não sei que hora, até que, morto de fadiga, encoste a cabeça à mesa e descanse uns minutos" (188). The rise and ruin of Paulo Honório and São Bernardo, then, have no effect on Casimiro's identity; he remains outside of the capitalist cycle. 
Like chapter nineteen of São Bernardo, the chapter "O soldado amarelo" in Vidas secas is a passage of destabilization and defamiliarization. At the beginning of the chapter, Fabiano is walking home from town when he runs into the soldier responsible for his incarceration, an event narrated in the earlier chapter "Cadeia." Startled by another body and not immediately aware of whose body it is, Fabiano's instinct is to kill; he begins to swing his machete. A twofold recognition stays the blow: "Viu apenas que estava ali um inimigo. De repente notou que aquilo era um homem e, coisa mais grave, uma autoridade" (152). A deconstruction of Fabiano's recognition process implies, first, the severity of the sertão and its inhabitants-an unknown body immediately signifies an enemy-and second, the way society nevertheless folds these inhabitants into a social order-Fabiano redirects his actions according to a social code in which the soldier's authority is inescapable. In this interpellation, there is also an intermediary step between blind action and recognition: Fabiano's realization of the other as himself, "um homem" (152). This consciousness speaks to Fabiano's empathy. Graciliano ascribes a heroic dignity to Fabiano (Hamilton 88 ), in contrast to the violence of the soldier's provocation and punishment of Fabiano in the town.

Although Fabiano's recognition of the soldier contextualizes him within an ideological apparatus in which he is subject to the other's power, the remainder of the chapter draws out their fleeting encounter-the reversal of Fabiano's instinct to strike-in such a way that problematizes this interpellation. For most of the chapter, Fabiano deliberates, on the verge of carrying out retributive violence. The dynamic of the encounter is paradoxical: Fabiano is impotent to act, visualizing the soldier's power; yet, he holds power over the soldier, who is lost and terrified of the vaqueiro. Fabiano's thought process formulates a defamiliarization of the social order. In the context of the isolated sertão, Fabiano perceives the limits of the soldier's authority, which is contingent upon the city space. The soldier "era dunga na cidade" (153), yet his power doesn't extend to the landscape of the sertão; his inability to navigate makes him dependent on Fabiano's knowledge. This amuses Fabiano, who realizes his fear of the soldier is ridiculous: "Tinha mêdo e repetia que estava em perigo, mas isto lhe pareceu tão absurdo que se pôs a rir. Mêdo daquilo? Nunca vira uma 
pessoa tremer assim" (153). This insight exceeds Fabiano's previous perception of the arbitrary injustice of the social order, a thought that takes hold in the first encounter with the soldier in yellow (Hamilton 89); his laughter at the notion of this system of authority transposed to the context of the sertão indicates a new comprehension of the material limits of power.

If the displacement of the encounter from the city to the sertão subverts the power dynamic between Fabiano and the soldier, this spatial and social decontextualization also renders uncertain the nature of Fabiano's subjectivity within or without dominant ideologies. As in chapter nineteen of São Bernardo, this destabilization manifests itself in the narrative treatment of time. Fabiano constitutes the single point of focalization for three distinct experiences of time.

In the first of these, Fabiano's sense of the soldier's and his own failure to realize an enactment of certain social roles results in a distended moment of inaction. The language that corresponds to this temporal suspension is that of equivocation: "Sentiu um choque violento, deteve-se, o braço ficou irresoluto, bambo, inclinando-se para um lado e para outro" (152-53); "estava indeciso, de ôlho arregalado, respirando com dificuldade ... o cabo do facão mal seguro entre os dedos úmidos" (153); "[e]ra um sujeito violento.... Não, era um cabra que se arreliava algumas vezes" (155); “[b]aixou a cabeça, coçou os pêlos ruivos do queixo.... Devia sujeitar-se àquela tremura, àquela amarelidão?” (158); “[v] acilou e coçou a testa" (160). Fabiano vacillates between being one kind of subject-“um sujeito violento" (155), a mythical cangaceiro that would avenge himself in the isolated caatinga-and another-an "acanalhado e ordeiro" sertanejo in the presence of an authority figure (160). In this temporal void, he is neither. In this sense, Fabiano is not yet a subject, a position of indeterminacy that belies the Althusserian notion of the individual as "always-already" a subject (Althusser 1357). By not locating the moment ideologically through some sort of communication that would resolve the indeterminate social relationship and therein realize the social order, Fabiano eludes his own subjectivity.

It is clear that on this discursive level, the uncertainty of the encounter grants Fabiano some power of which his normal social interactions deprive him. In the landscape of the caatinga, Fabiano's ability surpasses that of the soldier: Fabiano "espiava o chão como de costume, decifrando rastos" (151); the 
soldier, "magrinho, enfezadinho, tremia" (153). The soldier cowers ("encolhiase, escondia-se"), waiting for a cue from Fabiano (154). It is the latter that must act in order to manifest the ideologies of the social order, either by violating or adhering to this structure; it is up to Fabiano to interpellate both himself and the soldier into a known - that is, into an ideologically demarcated-dynamic.

Within this moment of suspension, however, Fabiano ruminates on his own futility and inability to effect an orientation for his identity as a subject. He despairs at the fact that the soldier refuses to hail him: "Esperou que êle se mexesse.... Ia bater o pé, gritar, levantar a espinha, plantar-lhe o salto da reiúna em cima da alpercata. Desejava que êle fizesse isso" (157); "[s]e o soldado não puxasse o facão, não gritasse, êle Fabiano seria um vivente muito desgraçado" (158). To Fabiano's mind, it is the soldier who will decipher the encounter, and he ascribes the disconnect between them in this moment to the soldier's inability to read the situation: Fabiano "[i]rritou-se. Porque seria que aquêle safado batia os dentes como um caitetu? Não via que êle era incapaz de vingar-se? Não via?" (154). On an existential level, this series of questions articulates the problem of Fabiano's subjectivity. Not only does he lack the agency to be an operative actor within the social order, he is incapable of being seen by society at all. The pared-down repetition of the question of whether the soldier sees Fabiano affirms this as the condition of Fabiano's existence; just as the townspeople who bump into him at the feast day seem incapable of seeing him, the soldier is now unable to see him as a person. If the abuse the soldier inflicts on Fabiano in the town gives rise to the latter's idea of the injustice of the social order (Hamilton 89), it also causes Fabiano to conceptualize himself within this social order; by contrast, here the same soldier's failure to enact the social order destabilizes Fabiano's understanding of his own existence. The temporality of void that operates in the chapter "O soldado amarelo," then, parallels the problem of Fabiano's voice, his identity almost completely isolated from society.

If indeterminacy, epistemological crisis and the collapse of identity characterize the dominant temporality of this scene, flashback and fantasy constitute its other two temporalities. Fabiano's recognition of the soldier who jailed him wrests his thoughts from the present and brings back his memory of that night: "agora suava frio e tinha lembranças insuportâveis" (155). He remembers 
the events that gave rise to his awareness of injustice. He goes on to remember his younger self: "Recordou-se de lutas antigas, em danças com fêmea e cachaça. Uma vez, de lambedeira em punho, espalhara a negrada. Aí sinha Vitória começara a gostar dêle" (158). Through this flashback, Fabiano reclaims an agency and a visibility of which the narrative moment has dispossessed him.

The flashback devolves into a sense of erasure of Fabiano's identity in the present: "Como a gente muda! Era. Estava mudado. Outro indivíduo, muito diferente do Fabiano que levantava poeira nas salas de dança. Um Fabiano bom para agüentar facão no lombo e dormir na cadeia. Virou a cara, enxergou o facão de rasto. Aquilo nem era facão, não servia para nada" (159). Fabiano’s fixation on the machete's impotence signifies his anxiety about his own loss of virility. Beyond this obvious symbolism, however, there is a more radical implication of Fabiano's perception of the moment: by not assuming its proper iteration as an object of violence, the machete fails to exist- "[a]quilo nem era facão" (159). Thus, even the material world eludes interpellation in this scene. Fabiano's sense of social disconnection distorts space and time. In this disintegration, he himself may no longer exist: while affirming his insight about change, the one-word sentence "Era" also carries a valence of existential doubt. Fabiano existed when he was seen by the people at the dance; now "outro," he is alienated even from himself.

Fabiano continues to reflect on the machete: "Quem disse que não servi? Era um facão verdadeiro, sim senhor.... Se aquela coisa tivesse durado mais um segundo, o polícia estaria morto" (159). The imagined resurrection of the weapon catalyzes a jump from a temporality of flashback to one of fantasizing about a conditional future: "Imaginou-o assim, caído.... Muito bem! Ia arrastá-lo para dentro da catinga, entregá-lo aos urubus. E não sentiria remorso. Dormiria com a mulher, sossegado, na cama de varas. Depois gritaria aos meninos, que precisavam criação. Era um homem, evidentemente" (159). In the same way that he draws upon his memory to reaffirm his existence, Fabiano's drafting of a simple fantasy of the conditional future serves as a declaration of his identity.

Both flashback and fantasy, then, are attempts to assert identity, which the suspended moment of the encounter between Fabiano and the soldier 
threatens. The scene ends with a restoration of ideological social order and both men's identities: the soldier, "[v]endo-o [Fabiano] acanalhado e ordeiro" ... "ganhou coragem, avançou, pisou firme, perguntou o caminho. E Fabiano tirou o chapéu de couro. -Govêrno é govêrno. Tirou o chapéu de couro, curvou-se e ensinou o caminho ao soldado amarelo" (160). The resolution of the indeterminate encounter with the soldier's resumption of power closes the ideological loophole that has prompted a temporal vacuum; the playing out of ideology re-interpellates both soldier and sertanejo.

Or so it would seem. In fact-as with Paulo Honório's polysemous assertion that money is money in São Bernardo-in Fabiano's tautological remark there remains a critical ambiguity. "Govêrno é govêrno" recalls his doubt during his first encounter with the soldier: "E, por mais que forcejasse, não se convencia de que o soldado amarelo fosse govêrno. Govêrno, coisa distante e perfeita, não podia errar. O soldado amarelo ... era fraco e ruim.... O govêrno não devia consentir tão grande safadeza" (43). In this earlier scene of submission to power, Fabiano's skepticism and analytical insight demonstrate a resistance to the ideologies that would create his subjectivity. Despite his obedience, Fabiano clearly distinguishes between justice and the corrupt code the soldier embodies: "govêrno" is transcendent, and the soldier is depraved. Thus, at the end of this second encounter with the soldier, "[g]ovêrno é govêrno" is evasive: is it the law of the soldier or a more sublime justice that Fabiano avows? If-consistent with Fabiano's thoughts in the earlier chapter- "govêrno" is a force apart from the soldier's actions, who is the soldier? Does this language accord with or belie Fabiano's bodily gesture of yielding to the soldier's power? If these words are indeed a repudiation of the soldier's identity as the embodiment of the law, Fabiano breaches the boundaries of his own subjectivity by claiming an identity neither brutish nor simple but subtle, analytical and clever. Furthermore, Fabiano refigures the soldier's subjectivity through a different lens, one that is based on an ideal of justice: the soldier is not law. It is precisely through language, then, that Fabiano challenges the social order. Through the subtlety of his utterance, Fabiano eludes both the corporal repression in which his overtly aggressive resistance resulted in the first encounter with the soldier and the subjectivity into which the dominant ideologies of society would interpellate him. Both in 
its circular syntax and in its evocation of his disavowal of the ideological apparatus the soldier would enact, then, Fabiano's comment does not allow for closure.

\section{Outside Hegemonic Language: Literary Discourse and Silent Sertanejos}

Fabiano's cogitation and rhetorical abilities in language complicate the notions that he is "guided by instinct rather than by thought" (Dimmick xxv); that "ratiocination is beyond his capabilities" (xxv); that "[n]a sua extraordinária simplicidade, não é propriamente o sujeito de sua vida" (Pereira Pinto 134); or that he doesn't think but rather "existe, simplesmente" (Candido, "Ficção" 45), a mere embodiment of "mecanismos da associação e da participação" (45). Even Vida seca's narration conspires in this disavowal of the sertanejo's agency of thought, despite the fact that the novel is largely comprised of Fabiano's thoughts: "Tinha muque e substância, mas pensava pouco, desejava pouco e obedecia" (37).

It is precisely in his misuse of language that Fabiano troubles an ideological apparatus that would limit him to brutish simplicity, violence or abulia. In fact, Fabiano's caginess with language is strategic; his interiority suggests a capacity for greater expression. He thinks in metaphor: "Seu Tomás fugira também, com a sêca, a bolandeira estava parada. E êle, Fabiano, era como a bolandeira" (15). He exploits society's asumption of his ignorance in order to evade the language of authority figures: "E, com ela, o fazendeiro, que o expulsara. Fabiano fizera-se desentendido e oferecera os seus préstimos, resmundando, coçando os cotovelos, sorrindo aflito" (23). Against his boss's abuse, his claim of ignorance becomes a protective refrain: "Não entendia de imposto. -Um bruto, está percebendo?” (141). Fabiano's “aceitação da força e [o] peso da tradição" may account for his limited use of language (Pereira Pinto 134); on the other hand, it may be that Fabiano perceives the violence entailed in submitting to "uma linguagem do homem 'civilizado', que, por estar inserido na vida em sociedade, obedece às convenções que tal condição impõe, inclusive aquelas relativas à linguagem” (Santos 37). Either way, Fabiano is ultimately not the stereotype of a simple sertanejo.

In the final chapter of the novel, Fabiano and his family are forced to flee once more. The chapter consists of the communication between Fabiano and sinha Vitória. Although the narrator first characterizes their dialogue as 
"cheia de mal-entendidos e repetições" (183), they persevere in forging a language of facial expressions, gesticulations and non-semantic signifying sounds like laughter. Here, despite the apparent misuse of their spoken language-it is completely incongruous with their material reality-their words imbue each other with hope: "Inventava o bebedouro, descrevia-o, mentia sem saber que estava mentindo. E sinha Vitória excitava-se, transmitia-lhe esperanças” (188); "[n]ão sentia a espingarda, o saco, as pedras miúdas que lhe entravam nas alpercatas, o cheiro de carniças que empestavam o caminho. As palavras de sinha Vitória encantavam-no. Iriam para diante, alcançariam uma terra desconhecida” (192). In his Benjaminian reading of the novel, Fábio José dos Santos shows that this conceptualization of and within language "diz o mundo e, na medida em que o diz, o cria.... [A]s personagens desse romance, lutando simbolicamente, denunciam a insuficiência da realidade em que vivem. Do mundo em ruínas nasce a poesia, que é a lugar de resistência e meio silencioso de denunciar as faltas do mundo" (149-50). If in Graciliano's writing, language is central to the possibility of intervening in one's world (Pereira Pinto 69), and thus of becoming human (Pereira Pinto 35), the retirantes' varied use of language disproves the notion that there is only one hegemonic (lettered) mode of expression that can bring about this humanization.

In fact, in both Vidas secas and São Bernardo, it is in the unsaid, unhearable, and unauthoritative forms of language where one finds an opening in what seem to be ideologically closed worlds. In chapter 19 of São Bernardo and "O soldado amarelo" in Vidas secas, where a defamiliarization of language and time puts ideological frameworks in crisis and subjectivities in doubt, the subsequent stabilization of language serves to suture these ruptures; Paulo Honório returns to the enactment of ideology, Fabiano defers to the figure of authority. These moments are critical to the discussion of ideology and language because they call the reader's (and the characters') attention to the social structures that prevailing ideologies impose; they also signal the deliberate thematization of these structures, thus precluding the normalization of the ideological apparatus within the literature itself. However, a more constant opening in ideology is present in the alternate languages of both storyworlds' marginalized characters: Fabiano and Vitória, Casimiro Lopes, Margarida. 
Like Fabiano and Vitória, Casimiro misuses language. Paulo Honório observes the disconnect between the language of Padilha and Casimiro:

\begin{abstract}
Não se entendem.... No sertão [Casimiro] passava horas calado, e quando estava satisfeito, aboiava. Quanto a palavras, meia dúzia delas. Ultimamente, ouvindo pessoas da cidade, tinha decorado alguns termos, que empregava fora de propósito e deturpados. Naquele dia, por mais que forcejasse, só conseguia dizer que as onças são bichos brabos e arteiros. -Pintada. Dentão grande, pezão grande, cada unha! Medonha! Padilha exigia que o outro repetisse a descrição e ia intercalando nela, por conta própia, caracteres novos. Casimiro Lopes divergia; mas confiado na ciência de Padilha, capitulava e ao cabo de minutos a onça estava um animal como nunca se viu. (56-57)
\end{abstract}

Here, Paulo Honório projects the phantasm of his own linguistic inferiority to Madalena onto Casimiro. A different reading of this encounter, however, reveals that Casimiro's language is radically different, and that even in his appropriations of the language of city folk, his is a language Padilha cannot understand. Furthermore, this language surpasses Padilha's literate, worldly language, as it is the latter who fails to describe the onça.

If Casimiro's misuse of appropriated language comes across in this passage, so too does his tendency toward silence. More so than Fabiano's, Casimiro's presence in society is a silent one. He crouches down, keeps watch, listens, but almost never speaks. Unlike in the case of Fabiano, however, even Casimiro's interiority is concealed from the narrative itself. He remains Other, then, not just within the storyworld but also within the text itself, an unwritten identity, an uninterpellated individual.

There emerges in Graciliano's novels a certain resistance related to language-a resistance within language, in its misuse (circularity, lying, [mis] appropriation); and a resistance to language, in the presence of silence. This resistance is more than a mere stylistic hallmark of Graciliano's writing or the result of a reticent or unsatisfied authorial voice, as Candido has argued: "preferia o silêncio ... devia ser para ele uma espécie de obsessão, tanto assim que 
quando corrigia ou retocava os seus textos ... só cortava, cortava sempre, numa espécie de fascinação abissal pelo nada” (“50 anos” 102). Not necessarily an act of cutting out, silence is sometimes an addition to the texts, its own discourse. What, then, is the significance of linguistic resistance within the context of literature? Specifically, what does this resistance in São Bernardo and Vidas secas bring to the body of Regionalist literature on Brazil's Northeast, of which (in most critical interpretations) Graciliano's work forms a part?

The discursive construction of the Northeast is linked to its droughts, the mythologization of which comes to characterize literature about the region (Greenfield 100). In critical texts, a sense of the Northeast's specifically literary-tragic character emerges. For example, Josué de Castro writes in his 1969 book Death in the Northeast: "one has the impression the whole landscape of the Northeast is a 600,000-square-mile stage set for some high tragedy" (22, italics my own); "as misery piles up, the stage is set for rebellion" (25, italics my own). In Os sertões, published in 1902, the almost pathological severity of the land predetermines the figure of the sertanejo, whose austerity of character and whose physicality take on similar language:

É desgracioso, desengonçado, torto.... A pé, quando parado, recosta-se invariavelmente ao primeiro umbral ou parede que encontra; a cavalo, se sofreia o animal para trocar duas palavras com um conhecido, cai logo sobre um dos estribos, descansando sobre a espenda da sela. Caminhando, mesmo a passo rápido, não traça trajetória retilínea e firme. Avança celeremente, num bambolear característico.... Reflete a preguiça invencível, a atonia muscular perene, em tudo. (48)

Euclides's conception of the sertão and its inhabitants endures in much of the Northeastern Regionalist aesthetic. Within this imaginary, there emerge "such stock characters as impoverished, ignorant backlanders prone to religious mysticism and fanaticism, and avaricious local bosses who readily employ violence to achieve their corrupt ends" (Greenfield 100). As a discursive system, the Northeast becomes an ideological apparatus that generates stereotypesthe jagunço outlaw (Vasconcelos 162), the violent cangaceiro, the transient 
retirantes, the "lazy sertanejo" (Greenfield 102) - and epistemological repression: "Who would anticipate anything other than decline from a primitive, ignorant, tradition-bound people who lived in an almost barbarous fashion?" (Greenfield 102). Some contemporary literary criticism continues to reproduce these stereotypes by citing a tension between "erudite" narrative voice and sertanejo voice in Regionalist texts (Vasconcelos 169), or "sophisticated and refined" aesthetics and "the northeast and its problems" (Reis 232).

These dichotomies in the critical reading of Regionalist literature imply the existence of an insurmountable incongruity between sertanejos and the literary text, as well as the limited lucidity of sertanejos. It is clear, however, that the uses of language by Graciliano's sertanejo characters call for an expanded understanding of subtleties in modes of expressivity; and, while Graciliano is recognized as unique among Regionalist writers for his representation of a transcendent human condition (Bueno 23, Santos 149), close reading for these subtleties in the silence or self-expression of sertanejos in other Regionalist texts might yield a different kind of criticism on Regionalist literature.

In her investigation of the historiographical construction of the Canudos rebellion, Adriana Michéle Campos Johnson maintains that the Northeast and its history are a literary invention. ${ }^{1}$ She takes as an underlying premise Homi Bhahba's idea of history as simultaneously narrative and condemnatory language, the "sentence of history" (Campos Johnson 1). Indeed, this kind of language creates, reframes and reduces, all the while avowing its own authority. As the field of subaltern studies has shown, the language through which discursive identities take shape tends to originate in elite, lettered communities and thus results not only in the problem of "the intellectual as the voice of the voiceless" (5), but also the very notion of this supposed voicelessness, the "production of subalternity itself" (John Beverley, qtd. in Rabasa 246).

Within this context, the resistance within and to language in the novels of Graciliano becomes a resistance to the production of voiceless subjects. Because of their improper languages (including silence and body language), society excludes people like Fabiano and Casimiro; as a consequence, they remain unincorporated into dominant forms of language (unlike Paulo Honório, who becomes enslaved by language, and unlike Madalena or Tomás da 
Bolandeira, whose ability with authorized language gives them social prestige). In Graciliano's novels, silence is its own language; it is also a recognition and marker of, as well as insistence upon, languages that exist outside of literature. Thus, aside from the effort to "dar voz a indivíduos que pouco contato têm com o mundo da linguagem" (Novaes Marinho 84), Graciliano inscribes in literature the recognition of its own limits, the intimation of its own outside-in Fabiano's interiority and ability to submit the language of power to philosophical questioning, in Casimiro's silence, in various characters' refusal to reproduce or correctly produce language. As textual entities, these characters channel different and sometimes unspoken discourses through the corpus of Brazil's Regionalist literature, asserting both the presence of otherness within this literature (and region) and an outside to ideological discourses of the Northeast or sertanejo identity. In this, São Bernardo and Vidas secas do not close off the ideological worlds they depict, but create openings for other identities, other paradigms, and other languages.

\section{Note}

1 She is not the only or first person to make this observation; see Albuquerque. Similarly, Vasconcelos writes: "The sertão has been a theme in Brazilian literature almost since its beginnings.... It was a cultural notion but, more than anything else, it was 'sheer literature"' (164).

\section{Works Cited}

Abbott, H. Porter. The Cambridge Introduction to Narrative. $2^{\text {nd }}$ ed. New York: Cambridge UP, 2008. Print.

Albuquerque Jr., Durval Muniz de. A invenção do nordeste e outras artes. São Paulo: Cortez, 1999. Print.

Althusser, Louis. from Ideology and Ideological State Apparatuses: Notes Towards an Investigation. 1970. The Norton Anthology of Theory and Criticism. $2^{\text {nd }}$ ed. Ed. Vincent B. Leitch. New York and London: Norton, 2010. 1335-61. Print.

Bakhtin, Mikhail. "Forms of Time and of Chronotope in the Novel: Notes Toward a Historical Poetics." Trans. Caryl Emerson and Michael Holquist. Narrative Dynamics: Essays on Time, Plot, Closure, and Frames. Ed. Brian Richardson. Columbus: Ohio State UP: 2002. 15-24. Print. 
Bueno, Luís. "Divisão e unidade no romance de 30." Literatura brasileira 1930. Ed. Andréa Sirihal Werkema, José Américo Miranda, Maria Cecília Boechat, Silvana Maria Pessôa de Oliveira. Belo Horizonte: U Federal de Minas Gerais, 2012. Print.

Campos Johnson, Adriana Michéle. Sentencing Canudos: Subalternity in the Backlands of Brazil. Pittsburgh: U of Pittsburgh P, 2010. Print.

Candido, Antonio. "50 anos de Vidas secas." Ficção e confissão: Ensaios sobre Graciliano Ramos. Rio de Janeiro: Editora 34, 1992. 102-08. Print.

—_. "Ficção e confissão." Fiç̧ão e confissão: Ensaios sobre Graciliano Ramos. Rio de Janeiro: Editora 34, 1992. 13-70. Print.

__. "Os bichos do subterrâneo." Ficção e confissão: Ensaios sobre Graciliano Ramos. Rio de Janeiro: Editora 34, 1992. 71-91. Print.

Castro, Josué de. Death in the Northeast. New York: Vintage, 1969. Print.

Certeau, Michel de. The Practice of Everyday Life. Trans. Steven F. Rendall. Berkeley: U of California P, 1984. Print.

Cunha, Euclides da. Os sertões. 1902. Ministério da Cultura, Fundação Biblioteca Nacional, Departamento Nacional do Livro. Web. 28 Nov. 2013.

Dimmick, Ralph Edward. "Introduction." Vidas secas. By Graciliano Ramos. Rio de Janeiro: Olympio, 1947. vii-xxxiv. Print.

Greenfield, Gerald M. "Drought and the Image of the Northeast." The Brazil Reader: History, Culture, Politics. Ed. Robert M. Levine and John J. Crocitti. Durham: Duke UP, 1999. 100-03. Print.

Hamilton, Russell G. “Character and Idea in Ramos' Vidas Secas." Luso-Brazilian Review 5.1 (1968): 86-92. Print.

Lafetá, João Luiz. "O mundo à revelia." São Bernardo. By Graciliano Ramos. $38^{\text {th }}$ ed. Rio de Janeiro: Record, 1981. 189-213. Print.

Lins, Álvaro. "Valores e misérias das vidas secas." Vidas secas. By Graciliano Ramos. $61^{\text {st }}$ ed. São Paulo: Record, 1991. Print.

Monteiro, Adolfo Casais. O romance: teoria e crítica. Rio de Janeiro: Olympio, 1964. Print.

Novaes Marinho, Maria Celina. A imagem da linguagem na obra de Graciliano Ramos: uma análise da heterogeneidade discursiva nos romances Angústia $e$ Vidas secas. São Paulo: Humanitas, 2000. Print.

Pereira Pinto, João. A libertade em Graciliano Ramos: Uma iniciação à antropologia e à ética. Santa Clara (Brazil): Contagem, 2001. Print.

Rabasa, José. "Pre-Columbian Pasts and Indian Presents in Mexican History." Dispositio. 19. 46 (1994): 245-70. Print.

Ramos, Graciliano. Memórias do cárcere. $12^{\text {th }}$ ed. Rio de Janeiro: Record, 1979. Print.

—. São Bernardo. $38^{\text {th }}$ ed. Rio de Janeiro: Record, 1981. Print.

- Vidas secas. $2^{\text {nd }}$ ed. Rio de Janeiro: Olympio, 1947. Print.

Reis, Roberto. "Who's Afraid of (Luso-)Brazilian Literature?" World Literature Today 62. 2 (1988): 231-34. Print.

Santos, Fábio José dos. Linguagem, poesia e resistência em Vidas secas. Alagoas: U Federal de Alagoas, 2009. Print. 
Sarmento Lima, Roberto. “Apresentação: Uma poesia no sertão." Linguagem, poesia e resistência em Vidas secas. By Fábio José dos Santos. Alagoas: U Federal de Alagoas,, 2009. Print.

Vasconcelos, Sandra Guardini T. "The Magic of Words: João Guimarães Rosa and the Backlands." Portuguese Studies 12 (1996): 158-70. Print.

Holly Jackson is a PhD student in Hispanic Languages and Literatures in the Department of Spanish and Portuguese at the University of California, Berkeley. 